\title{
EFFECT OF DIFFERENT RESOURCES AND METHODS OF SILICON AND ZINC APPLICATION ON AGRONOMIC TRAITS, NUTRIENT UPTAKE AND GRAIN YIELD OF RICE (ORYZA SATIVA L.)
}

\author{
KHEYRI, N. ${ }^{1}-$ AJAM NOROUZI, H. ${ }^{1 *}-$ MOBASSER, H. R. ${ }^{2}-$ TORABI, B. ${ }^{3}$ \\ ${ }^{I}$ Department of Agronomy, Gorgan Branch, Islamic Azad University, Gorgan, Iran \\ ${ }^{2}$ Department of Agronomy, Ghaemshahr Branch, Islamic Azad University, Ghaemshahr, Iran \\ ${ }^{3}$ Department of Agronomy, Gorgan University of Agricultural Sciences and Natural Resources \\ Gorgan, Iran \\ *Corresponding author \\ e-mail:ajamnorozei@yahoo.com \\ (Received $16^{\text {th }}$ Feb 2018; accepted $18^{\text {th }}$ May 2018)
}

\begin{abstract}
To evaluate the effect of different resources and methods of silicon ( $\mathrm{Si}$ ) and zinc ( $\mathrm{Zn}$ ) application on agronomic traits, nutrient uptake and grain yield of rice (Oryza sativa L.), a field experiment was conducted as a randomized complete block design with 16 treatments and three replications in Noor region, Mazandaran province, Iran in the crop year of 2015-2016. The experimental treatments included the different resources and forms of $\mathrm{Si}$ and $\mathrm{Zn}$ application as nanoparticles (NPs) foliar application and soil application of the elements. The results indicated that grain and straw yields were increased in response to application of $\mathrm{Si}$ and $\mathrm{Zn}$ fertilizers. All fertilized treatments had significantly higher yields than the control, although yields did not differ significantly between the fertilized treatments. The experimental treatments significantly affected the yield components, $\mathrm{Si}, \mathrm{Zn}$ and $\mathrm{N}$ concentrations in the plant tissue. The combined application of $\mathrm{Si}$ and $\mathrm{Zn}$ by both methods, either via NPs foliar application or soil application resulted in an increase in the grain and straw yields, yield components and $\mathrm{Si}, \mathrm{Zn}$ and $\mathrm{N}$ concentrations in rice grain and straw. According to the results of this research, the combined application of Si plus Zn, especially by NPs foliar application, is appropriate for increasing the production of the rice crop in Noor Region of Iran.
\end{abstract}

Keywords: crop yield, foliar application, rice, soil application, silicon, zinc

\section{Introduction}

Silicon ( $\mathrm{Si}$ ) and zinc ( $\mathrm{Zn})$ as macro and micronutrients, respectively have a key role in improving growth and increasing grain yield of plants, and their deficiency can make a serious problem for crop production, especially in the case of rice. Silicon is the second most abundant mineral in the soil (Kafi and Rahimi, 2011), that is a useful nutrient for healthy growth and sustainable production of rice (Tamai and Ma, 2008). Silicon has a dual effect on the plant and soil system, which, by being absorbed in the plant, makes the plant more resistant to pests, diseases and environmental stresses, and, on the other hand, led to soil fertility by improving water, physicochemical properties of soil and maintaining the nutrients in available form for the plant (Meena et al., 2014). Soil silicon has several benefits for rice including the reduction of the adsorption of heavy metals such as Pb (Jianguo et al., 2015), Cd (Lin et al., 2016), and As (Wu et al., 2015), resistance to salt stress (Mahmoud et al., 2017), increasing the extent of photosynthesis, the improvement of performance, the prevention of lodging (Jeer et al., 2017), as well as the reduction of the negative effects of ultraviolet radiation on the 
physiological processes of photosynthesis and transpiration (Lou et al., 2016). The modern silicon fertilizers (nano-SiO2) easily penetrate into the leaves and create a thick silicate layer on the leaf surface (Meena et al., 2014). Silicon plays an important role in increasing the activity of antioxidant enzymes and enhancing the content of osmolites, in contributing to the resistance of abiotic and biotic stresses in plants (Amiri et al., 2014). Reports indicated that the use of Si increases the grain yield of rice by increasing the number of whole spikelets (Mobasser et al., 2008) and the number of fertile tillers per hill (Ghasemi Mianaei et al., 2011). Other researchers reported that the Si application significantly increased the tiller number and $\mathrm{Si}$ concentration in the plant (Zia et al., 2017). Cuong et al. (2017) reported that increase in Si application, increases the $\mathrm{Si}$ absorption and other nutrients such as nitrogen, phosphorus and potassium in rice biomass (grain + straw) compared to control.

Zinc, after nitrogen and phosphorus, is the most important nutrient that limits the grain yield of rice (Yakan et al., 2000), and is a global concern for human nutrition (Farooq et al., 2018). Zinc as a cofactor of antioxidant enzymes such as catalase and peroxidase plays an important part in plant protection and ultimately improves yield (Samart et al., 2017). Zinc has an important role in several physiological processes of the plants such as protein synthesis, enzyme activation, gene expression and carbohydrate metabolism (Chang et al., 2005; Qiao et al., 2014). Studies have shown that zinc improves the absorption of other nutrients such as potassium, phosphorus and iron for the plant (Amirjani et al., 2014). It has been reported that the application of nano- $\mathrm{ZnO}$ in the rates of 25 and $50 \mathrm{mg} . \mathrm{l}^{-1}$ improves the rice growth (Upadhyaya et al., 2014), but in higher concentrations due to the creation of toxicity by the accumulation of this element in the plant lead to reduction in plant growth and biomass (Boonyanitipong et al., 2011; Chen et al., 2015). The improvement of zinc concentration and enhancement of rice grain yield by $\mathrm{Zn}$ supply through soil (basal) +2 foliar applications have been reported in the results of other investigators (Saha et al., 2017). In a study, which the effects of zinc were evaluated by two methods of foliar application and soil application on yield and yield components of rice, reported that the number of fertile tillers, number of grains per panicle, 1000-grain weight, grain yield, harvest index and grain $\mathrm{Zn}$ concentration significantly increased compared to control using both methods (Farooq et al., 2018). Sudha and Stalin (2015) found that zinc application in soil with its foliar application significantly increased the agronomic and physiological traits.

The problem of accessibility to nutrients such as Si and $\mathrm{Zn}$ by usual methods results in an increase in the attention to the use of modern methods for application of these elements in recent years. Nanotechnology is one of the most modern methods in agricultural practices. The most important of its applications in different aspects of agriculture, that is in the water and soil section are the use of nano-fertilizers for plant nutrition (Mazlomi et al., 2012). Nanofertilizers are more effective in improving plant nutrition, increasing the efficiency of nutrient use, and protecting plants from environmental stresses than conventional fertilizers (Wang et al., 2015). The Maximum use of production sources, especially with the nano-fertilizers application, and enhancing photosynthesis efficiency can reduce the environmental risks associated with the excessive application of chemical fertilizers (Sepehri and Vaziri Amjad, 2015). Although nanotechnology in agriculture is less developed due to lower investment compared to other sectors, nanotechnology is very effective in improving agricultural production (Huang et al., 2015). 


$$
-5783-
$$

Therefore, the aim of the present study was to evaluate the effects of Si and $\mathrm{Zn}$ by applying different resources and methods to improve yield components, nutrient uptake and grain yield of rice.

\section{Materials and methods}

\section{Experimental site}

The field experiment was conducted during crop year of 2015-2016 in Noor region, Mazandaran province, Iran, located at $36^{\circ} 46^{\prime} \mathrm{N}$ latitude, $52^{\circ} 28^{\prime} \mathrm{E}$ longitude and $71 \mathrm{~m}$ above the sea level (Fig. 1). The meteorological data recorded during rice-growing seasons are presented in Table 1. The physical and chemical properties of the soil in the experimental site are shown in Table 2.

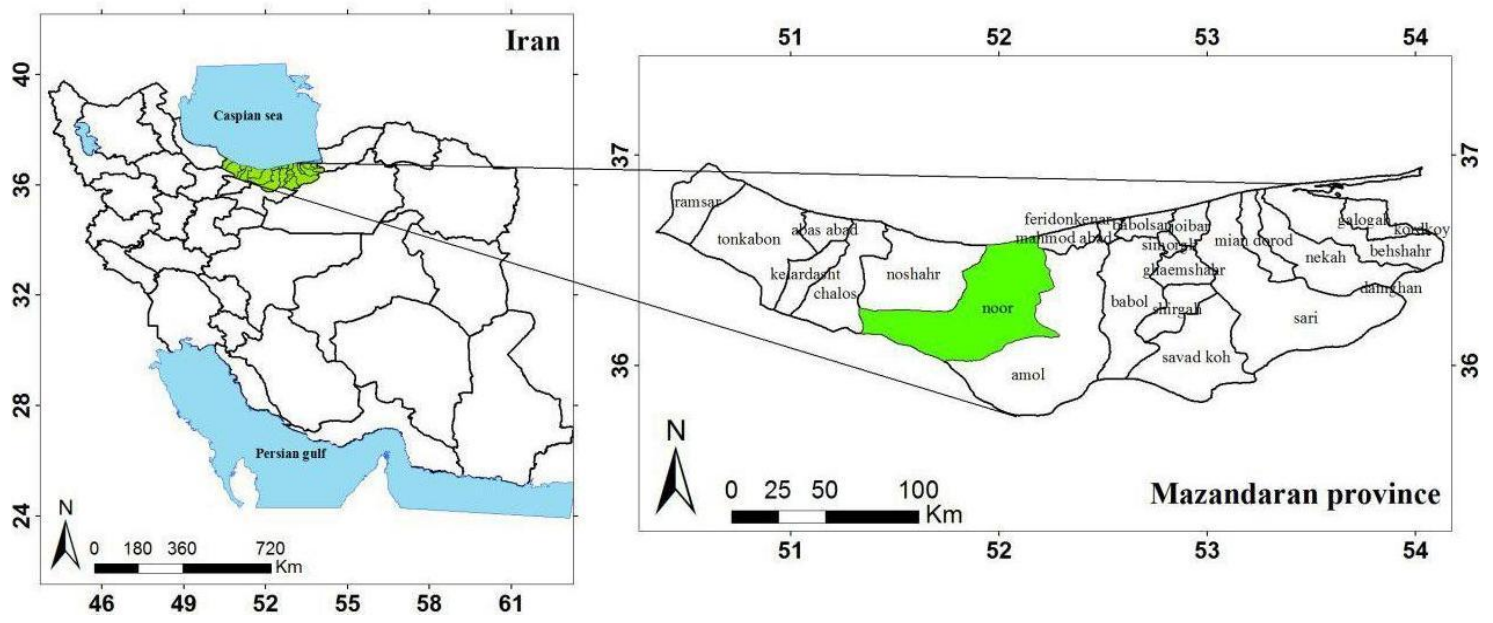

Figure 1. The study area location in Noor region, Mazandaran province, Iran

Table 1. Meteorological data recorded during rice-growing seasons of the experiment

\begin{tabular}{c|c|c|c|c|c|c}
\hline \multirow{2}{*}{ Month of the year } & \multicolumn{2}{|c|}{$\begin{array}{c}\text { Average of monthly } \\
\text { temperature }\left({ }^{\circ} \mathbf{C}\right)\end{array}$} & \multicolumn{2}{|c|}{$\begin{array}{c}\text { Average of monthly } \\
\text { relative humidity (\%) }\end{array}$} & $\begin{array}{c}\text { Total } \\
\text { monthly } \\
\text { rainfall (mm) }\end{array}$ & $\begin{array}{c}\text { Total sunny } \\
\text { hours (h) }\end{array}$ \\
\cline { 2 - 6 } & Minimum & Maximum & Minimum & Maximum & 129.8 & 121.1 \\
\hline March-April & 10.4 & 17.3 & 67 & 94 & 43.0 & 159.3 \\
April-May & 15.5 & 21.4 & 73 & 94 & 27.7 & 260.8 \\
May-June & 19.4 & 26.0 & 67 & 60 & 179.9 & 208.9 \\
June-July & 22.6 & 28.8 & 67 & 89 & 46.1 & 251.1 \\
July-August & 23.2 & 30.1 & 68 & 90 & 182.6 & 205.9 \\
August-September & 22.0 & 29.3 & 66 & 90 & & \\
\hline
\end{tabular}

Table 2. Physical and chemical characteristics of the soil in the experimental site in a depth of $0-30 \mathrm{~cm}$

\begin{tabular}{c|c|c|c|c|c|c|c|c|c|c|c|c}
\hline $\begin{array}{c}\text { Soil } \\
\text { texture }\end{array}$ & $\begin{array}{c}\text { Silt } \\
(\boldsymbol{\%})\end{array}$ & $\begin{array}{c}\text { Clay } \\
(\boldsymbol{\%})\end{array}$ & $\begin{array}{c}\text { Sand } \\
(\boldsymbol{\%})\end{array}$ & $\mathbf{p H}$ & $\begin{array}{c}\text { EC } \\
\left(\mathbf{d s . m}^{-1}\right)\end{array}$ & $\begin{array}{c}\text { SP } \\
(\boldsymbol{\%})\end{array}$ & $\begin{array}{c}\mathbf{O . C} \\
(\boldsymbol{\%})\end{array}$ & $\begin{array}{c}\mathbf{O . M} \\
(\boldsymbol{\%})\end{array}$ & $\begin{array}{c}\mathbf{P} \\
\left(\mathbf{m g . k g}^{-1}\right)\end{array}$ & $\begin{array}{c}\mathbf{K} \\
\left(\mathbf{m g . k g}^{-1}\right)\end{array}$ & $\begin{array}{c}\mathbf{Z n} \\
\left(\mathbf{m g . k g}^{-1}\right)\end{array}$ & $\begin{array}{c}\mathbf{S i} \\
(\boldsymbol{\%})\end{array}$ \\
\hline Loam & 44 & 20 & 36 & 7.51 & 3.02 & 63 & 1.66 & 2.86 & 10.5 & 116 & 0.81 & 0.28 \\
\hline
\end{tabular}




$$
-5784 \text { - }
$$

\section{Experimental layout, design and treatments}

This experiment was designed as a randomized complete block design with 16 treatments and 3 replications, thus there were 48 equal plots in size of $10 \mathrm{~m}^{2}(5 \mathrm{~m} \times$ $2 \mathrm{~m})$. The experimental treatments characteristics are presented in Table 3.

Table 3. The experimental treatments characteristics

\begin{tabular}{|c|c|}
\hline Treatments & Treatments characteristics \\
\hline \begin{tabular}{l|l}
$\mathrm{T} 1$ &
\end{tabular} & Control \\
\hline $\mathrm{T} 2$ & Soil application of calcium silicate \\
\hline $\mathrm{T} 3$ & Soil application of zinc sulfate \\
\hline $\mathrm{T} 4$ & Soil application of calcium silicate + zinc sulfate \\
\hline T5 & Foliar application of nano- $\mathrm{SiO}_{2}$ \\
\hline T6 & Foliar application of nano- $\mathrm{SiO}_{2}+$ soil application of calcium silicate \\
\hline $\mathrm{T} 7$ & Foliar application of nano- $\mathrm{SiO}_{2}+$ soil application of zinc sulfate \\
\hline $\mathrm{T} 8$ & Foliar application of nano- $\mathrm{SiO}_{2}+$ soil application of calcium silicate + zinc sulfate \\
\hline T9 & Foliar application of nano- $\mathrm{ZnO}$ \\
\hline $\mathrm{T} 10$ & Foliar application of nano- $\mathrm{ZnO}+$ soil application of calcium silicate \\
\hline T11 & Foliar application of nano- $\mathrm{ZnO}+$ soil application of zinc sulfate \\
\hline T12 & Foliar application of nano- $\mathrm{ZnO}+$ soil application of calcium silicate + zinc sulfate \\
\hline $\mathrm{T} 13$ & Foliar application of nano-SiO + nano- $\mathrm{ZnO}$ \\
\hline $\mathrm{T} 14$ & Foliar application of nano- $\mathrm{SiO}_{2}+$ nano- $\mathrm{ZnO}+$ soil application of calcium silicate \\
\hline T15 & Foliar application of nano-SiO ${ }_{2}+$ nano- $\mathrm{ZnO}+$ soil application of zinc sulfate \\
\hline T16 & $\begin{array}{c}\text { Foliar application of nano- } \mathrm{SiO}_{2}+\text { nano- } \mathrm{ZnO}+\text { soil application of calcium silicate }+ \text { zinc } \\
\text { sulfate }\end{array}$ \\
\hline
\end{tabular}

The land preparation practices were performed according to the conventional procedure, so that the land was disk-ploughed in late February and the complete practices including puddling and leveling were carried out in mid-May. An indica rice (Oryza sativa L.) cultivar Tarom Hashemi was used as plant material for the present research, which is an early rice cultivar that usually used by farmers in the north of Iran. The seed of rice cultivar Tarom Hashemi was obtained from the Rice Research Institute, Mazandaran, Iran. Rice seedlings were transplanted at a spacing of $20 \mathrm{~cm} \times 20 \mathrm{~cm}$ with four seedlings per hill in mid-May, and harvested in mid-August. For all treatments, phosphorus and potassium fertilizers were applied as basal at the rate of $70 \mathrm{~kg} \mathrm{ha}^{-1}$ as triple superphosphate and $100 \mathrm{~kg} \mathrm{ha}^{-1}$ as potassium sulfate, respectively. Urea was applied as nitrogen fertilizer uniformly for all the plots at the rate of $150 \mathrm{~kg} \mathrm{ha}^{-1}$ in three equal splits (one third at the time of transplanting, one third at the tillering stage and one third at the heading stage). For soil application, silicon and zinc fertilizers were applied as basal at the rate of $400 \mathrm{~kg} \mathrm{ha}^{-1}$ as calcium silicate and $40 \mathrm{~kg} \mathrm{ha}^{-1}$ as zinc sulfate, respectively. For foliar application, nano- $\mathrm{SiO}_{2}$ and nano- $\mathrm{ZnO}$ in the concentration of 50 $\mathrm{mg} \mathrm{L}^{-1}$ was applied in four stages of plant growth (early tillering stage, middle tillering, panicle initiation and full heading stage) in plots. Nanofertilizers used in the experiment were products of US Research Nanomaterials, Inc (Table 4). In order to control the weeds during growing stages, manual weeding was performed twice on days $14^{\text {th }}$ and $28^{\text {th }}$ after transplanting, and for its chemical control, Butakler's herbicide was applied in the concentration of $3.5 \mathrm{~L} \mathrm{ha}^{-1}$ a week after transplanting. Furthermore, in order to 


$$
-5785 \text { - }
$$

control Chilo suppressalis, diazinon insecticide (10\% granule) was used at a rate of 15 $\mathrm{kg} \mathrm{ha}^{-1}$ at the peak of tillering and heading stages (Fig. 2). The rice striped stem borer, Chilo suppressalis, is one of the most serious sources of damage to rice growth and production in Asia, northern Africa, and southern Europe (He et al., 2014).

Table 4. Analysis of silicon dioxide $\left(\mathrm{SiO}_{2}\right)$ and zinc oxide $(\mathrm{ZnO})$ nanoparticles

\begin{tabular}{c|c|c|c|c}
\hline NPs & Purity percentage & Particles size & True density & Color \\
\hline $\mathrm{SiO}_{2}$ & $>99 \%$ & $20-30 \mathrm{~nm}$ & $2.4 \mathrm{~g} / \mathrm{cm}^{3}$ & white \\
$\mathrm{ZnO}$ & $>99 \%$ & $10-30 \mathrm{~nm}$ & $5.606 \mathrm{~g} / \mathrm{cm}^{3}$ & Milky white \\
\hline
\end{tabular}

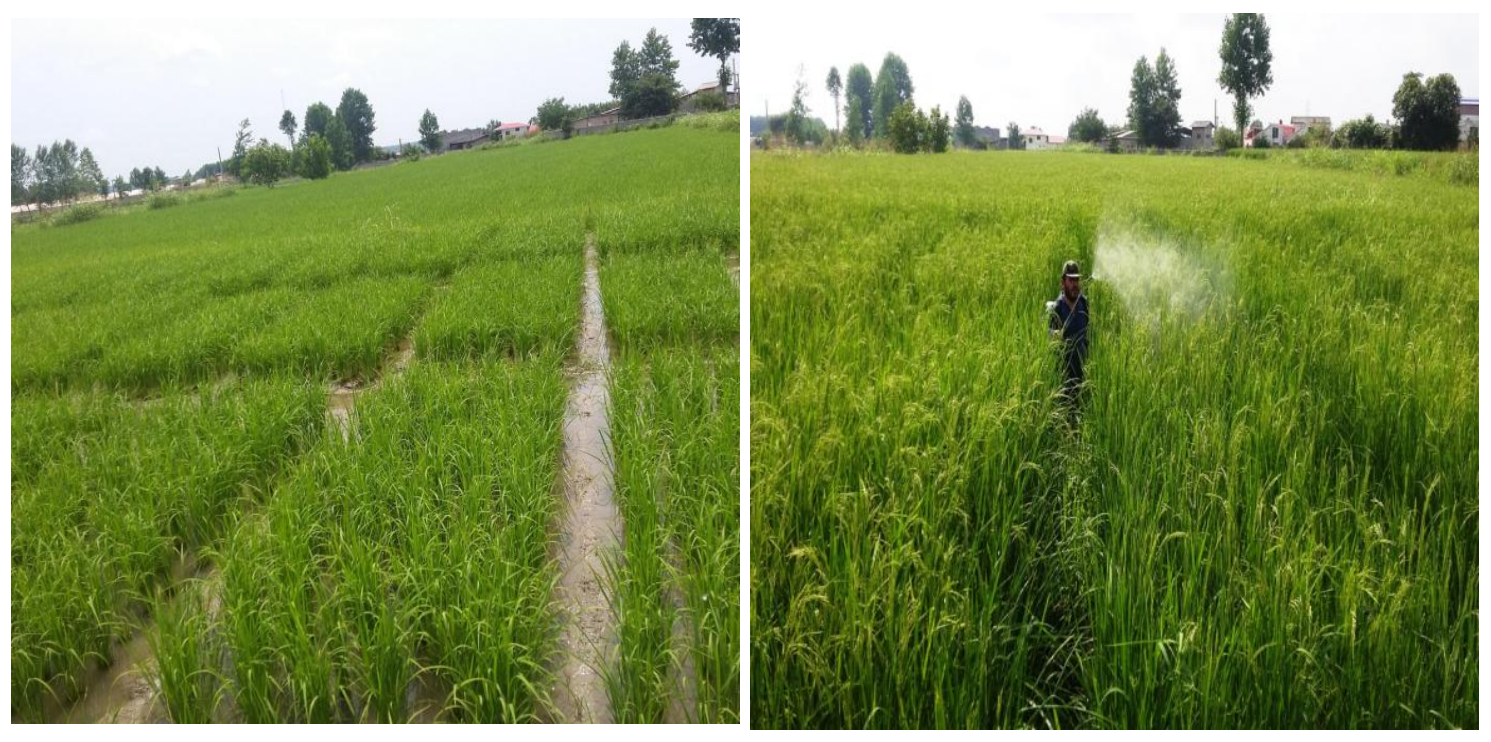

Figure 2. Photos of experimental field and fertilizer treatments application in growth stages of rice

\section{Sample preparation and $\mathrm{Si}, \mathrm{Zn}$ and $\mathrm{N}$ analysis}

During the flowering stage of the plant, chlorophyll content of flag leaf was measured using chlorophyll meter (SPAD-502, Minolta, Japan). At maturity, determination of plant height and panicle length were performed by measuring 12 plants in each plot. The number of fertile tillers per hill was determined by counting from 12 hill per plot, number of filled and unfilled grains per panicle were determined by counting from 20 panicles per plot and 1000-grain weight was determined by counting and weighing 10 samples of 100 seed. Grain and straw yields were determined by manually harvesting each plot $\left(2 \times 2 \mathrm{~m}^{2}\right)$, separating grains from straw and drying samples in an oven at $70{ }^{\circ} \mathrm{C}$ for $48 \mathrm{~h}$. Grain and straw samples were weighed with $14 \%$ moisture content and calculated based on kilograms per hectare.

Si concentration in plant samples (grain and straw) was determined by Yoshida method (Yoshida, 1975). Zn concentration in plant tissue was determined by Atomic Absorption Spectrophotometer (AAS) method (Emami, 1996). The N concentration in grain and straw was measured by micro-Kjeldahl method (Emami, 1996). Mobilization efficiency index (MEI) of Si, Zn and $\mathrm{N}$ was calculated as Equations 1, 2 and 3: 


$$
\begin{gathered}
\text { Si } M E I=\frac{\text { Si concentration in grain }(96)}{\text { Si concentration in straw (96) }} \\
Z n M E I=\frac{\mathrm{Zn} \text { concentration in grain }\left(\mathrm{mg} \cdot \mathrm{kg}^{-1}\right)}{\mathrm{Zn} \text { concentration in straw }\left(\mathrm{mg} \cdot \mathrm{kg}^{-1}\right)} \\
N M E I=\frac{\mathrm{N} \text { concentration in grain }(96)}{\mathrm{N} \text { concentration in straw }(96)}
\end{gathered}
$$

where $\mathrm{Si}=$ silicon, $\mathrm{Zn}=$ zinc, $\mathrm{N}=$ nitrogen, and $\mathrm{MEI}=$ mobilization efficiency index.

The mobilization efficiency index of the elements was calculated to determine the amount of transmission of these elements from straw to grain and their accumulation in grain.

\section{Statistical analysis}

The data were statistically analyzed using MSTATC software. Randomized complete block design was used for data analysis. The mean comparison was performed using the least significance difference (LSD) test at 5\% probability level. A simple linear regression was used to determine the relationship between the concentrations of Si and $\mathrm{Zn}$ in grain and straw with $\mathrm{N}$ concentrations in rice plant tissue and its yields.

\section{Results}

\section{Grain and straw yields}

In this study, grain and straw yields were increased in response to application of $\mathrm{Si}$ and $\mathrm{Zn}$ fertilizers. All fertilized treatments had significantly higher yield than the control, although its yield did not differ significantly between the fertilized treatments. The maximum grain yield $\left(4502 \mathrm{~kg} \mathrm{ha}^{-1}\right)$ and straw yield $\left(5933 \mathrm{~kg} \mathrm{ha}^{-1}\right)$ were obtained by the application of $\mathrm{T} 13$ (nano-SiO2 + nano-ZnO) and T16 (nano-SiO2 + nano-ZnO + calcium silicate + zinc sulfate) treatments, respectively. However, the combined application of $\mathrm{Si}$ and $\mathrm{Zn}$ had better effect in increasing grain and straw yields compared to individual application of each element (Table 5). There was a positive and significant linear correlation between rice grain and straw yields with the Si and $\mathrm{Zn}$ concentration in grain and straw at a probability level of $1 \%$, such that by increasing Si concentration in grain and straw $\left(\mathrm{R}^{2}=0.1588\right.$ and $\mathrm{R}^{2}=0.0714, \mathrm{P}<0.01$, respectively), and $\mathrm{Zn}$ concentration in grain and straw $\left(\mathrm{R}^{2}=0.1749\right.$ and $\mathrm{R}^{2}=0.2173, \mathrm{P}<0.01$, respectively), grain and straw yield increased (Fig. 3).

\section{Plant height and panicle length}

In this research, the plant height did not differ significantly comparing experimental treatments. While, the panicle length was significantly affected by the evaluated treatments. The panicle length was significantly increased by combination of both methods of NPs foliar application and soil application in different treatments, but the maximum panicle length $(26 \mathrm{~cm})$ was obtained by the foliar application of nano- $\mathrm{SiO}_{2}+$ nano-ZnO (T13), while the minimum panicle length $(21.67 \mathrm{~cm})$ was obtained in the control or no fertilizer application (Table 6). 


$$
-5787 \text { - }
$$

Table 5. Mean comparison of effect the experimental treatments on grain and straw yields of rice (cv. Tarom Hashemi)

\begin{tabular}{|c|c|c|}
\hline Treatments & Grain yield $\left(\mathrm{kg.ha}^{-1}\right)$ & Straw yield $\left(\mathrm{kg}^{2} \mathrm{ha}^{-1}\right)$ \\
\hline $\mathrm{T} 1$ & $3503 b$ & $4845 b$ \\
\hline $\mathrm{T} 2$ & $3834 \mathrm{ab}$ & $5316 \mathrm{ab}$ \\
\hline $\mathrm{T} 3$ & $4053 \mathrm{ab}$ & $5477 \mathrm{a}$ \\
\hline $\mathrm{T} 4$ & $4170 \mathrm{ab}$ & $5602 \mathrm{a}$ \\
\hline T5 & $4031 \mathrm{ab}$ & $5496 \mathrm{a}$ \\
\hline $\mathrm{T} 6$ & $4000 \mathrm{ab}$ & $5370 \mathrm{ab}$ \\
\hline $\mathrm{T} 7$ & $4210 \mathrm{ab}$ & $5543 \mathrm{a}$ \\
\hline $\mathrm{T} 8$ & $4358 \mathrm{ab}$ & $5477 \mathrm{a}$ \\
\hline T9 & $4133 a b$ & $5337 \mathrm{ab}$ \\
\hline $\mathrm{T} 10$ & $4121 \mathrm{ab}$ & $5389 \mathrm{ab}$ \\
\hline T11 & $4243 a$ & $5692 \mathrm{a}$ \\
\hline $\mathrm{T} 12$ & $4293 a$ & $5763 a$ \\
\hline $\mathrm{T} 13$ & $4502 \mathrm{a}$ & $5917 \mathrm{a}$ \\
\hline $\mathrm{T} 14$ & $4400 \mathrm{a}$ & $5827 \mathrm{a}$ \\
\hline T15 & $4388 \mathrm{a}$ & $5853 a$ \\
\hline T16 & $4423 a$ & $5933 a$ \\
\hline $\mathrm{LSD}_{0.05}$ & 717 & 626.7 \\
\hline
\end{tabular}

Values followed by different small letters within columns are significantly different $(\mathrm{p}<0.05)$ according to the LSD test

Table 6. Mean comparison of the effects of experimental treatments on agronomic traits of rice (cv. Tarom Hashemi)

\begin{tabular}{c|c|c|c|c|c|c|c}
\hline Treatments & $\begin{array}{c}\text { Plant } \\
\text { height } \\
\text { (cm) }\end{array}$ & $\begin{array}{c}\text { Panicle } \\
\text { length } \\
\text { (cm) }\end{array}$ & $\begin{array}{c}\text { No. of } \\
\text { fertile } \\
\text { tillers hill }^{-1}\end{array}$ & $\begin{array}{c}\text { No. of filled } \\
\text { grain } \\
\text { panicle }^{-1}\end{array}$ & $\begin{array}{c}\text { No. of } \\
\text { unfilled grain } \\
\text { panicle- }^{-1}\end{array}$ & $\begin{array}{c}\mathbf{1 0 0 0 -} \\
\text { grain } \\
\text { weight }(\mathbf{g})\end{array}$ & $\begin{array}{c}\text { Chlorophyll } \\
\text { content }\end{array}$ \\
\hline $\mathrm{T} 1$ & $135.2 \mathrm{a}$ & $21.67 \mathrm{~d}$ & $13.13 \mathrm{~h}$ & $81.53 \mathrm{f}$ & $20.60 \mathrm{ab}$ & $25.33 \mathrm{a}$ & $35.03 \mathrm{c}$ \\
$\mathrm{T} 2$ & $137.3 \mathrm{a}$ & $23.23 \mathrm{c}$ & $15.03 \mathrm{~g}$ & $88.03 \mathrm{~b}-\mathrm{f}$ & $15.93 \mathrm{c}-\mathrm{f}$ & $25.50 \mathrm{a}$ & $35.43 \mathrm{bc}$ \\
$\mathrm{T} 3$ & $138.4 \mathrm{a}$ & $24.40 \mathrm{bc}$ & $16.03 \mathrm{efg}$ & $87.60 \mathrm{c}-\mathrm{f}$ & $15.30 \mathrm{c}-\mathrm{f}$ & $25.60 \mathrm{a}$ & $36.20 \mathrm{abc}$ \\
$\mathrm{T} 4$ & $138.3 \mathrm{a}$ & $25.53 \mathrm{ab}$ & $16.57 \mathrm{~b}-\mathrm{f}$ & $97.07 \mathrm{ab}$ & $15.43 \mathrm{c}-\mathrm{f}$ & $25.20 \mathrm{a}$ & $36.07 \mathrm{abc}$ \\
$\mathrm{T} 5$ & $138.9 \mathrm{a}$ & $25.67 \mathrm{ab}$ & $15.90 \mathrm{efg}$ & $85.80 \mathrm{def}$ & $18.27 \mathrm{bc}$ & $25.67 \mathrm{a}$ & $35.70 \mathrm{abc}$ \\
$\mathrm{T} 6$ & $140.1 \mathrm{a}$ & $25.50 \mathrm{ab}$ & $15.53 \mathrm{fg}$ & $100.0 \mathrm{a}$ & $12.90 \mathrm{ef}$ & $25.00 \mathrm{a}$ & $36.40 \mathrm{abc}$ \\
$\mathrm{T} 7$ & $139.0 \mathrm{a}$ & $25.80 \mathrm{ab}$ & $16.50 \mathrm{c}-\mathrm{f}$ & $94.10 \mathrm{a}-\mathrm{d}$ & $17.00 \mathrm{bcd}$ & $25.50 \mathrm{a}$ & $37.03 \mathrm{abc}$ \\
$\mathrm{T} 8$ & $139.8 \mathrm{a}$ & $25.93 \mathrm{a}$ & $16.73 \mathrm{~b}-\mathrm{f}$ & $95.00 \mathrm{a}-\mathrm{d}$ & $16.50 \mathrm{cde}$ & $25.47 \mathrm{a}$ & $36.90 \mathrm{abc}$ \\
$\mathrm{T} 9$ & $140.1 \mathrm{a}$ & $25.80 \mathrm{ab}$ & $16.50 \mathrm{c}-\mathrm{f}$ & $90.93 \mathrm{a}-\mathrm{e}$ & $15.00 \mathrm{c}-\mathrm{f}$ & $25.73 \mathrm{a}$ & $36.30 \mathrm{abc}$ \\
$\mathrm{T} 10$ & $138.5 \mathrm{a}$ & $25.70 \mathrm{ab}$ & $16.37 \mathrm{~d}-\mathrm{g}$ & $94.40 \mathrm{a}-\mathrm{d}$ & $13.73 \mathrm{def}$ & $25.60 \mathrm{a}$ & $36.70 \mathrm{abc}$ \\
$\mathrm{T} 11$ & $139.2 \mathrm{a}$ & $25.57 \mathrm{ab}$ & $17.07 \mathrm{a}-\mathrm{e}$ & $83.50 \mathrm{ef}$ & $22.80 \mathrm{a}$ & $25.73 \mathrm{a}$ & $36.63 \mathrm{abc}$ \\
$\mathrm{T} 12$ & $140.8 \mathrm{a}$ & $25.77 \mathrm{ab}$ & $17.13 \mathrm{a}-\mathrm{e}$ & $88.93 \mathrm{~b}-\mathrm{f}$ & $17.00 \mathrm{bcd}$ & $25.50 \mathrm{a}$ & $37.67 \mathrm{ab}$ \\
$\mathrm{T} 13$ & $138.5 \mathrm{a}$ & $26.00 \mathrm{a}$ & $18.47 \mathrm{a}$ & $93.90 \mathrm{a}-\mathrm{d}$ & $13.37 \mathrm{def}$ & $25.63 \mathrm{a}$ & $37.33 \mathrm{abc}$ \\
$\mathrm{T} 14$ & $141.0 \mathrm{a}$ & $25.93 \mathrm{a}$ & $17.70 \mathrm{a}-\mathrm{d}$ & $95.50 \mathrm{abc}$ & $12.60 \mathrm{f}$ & $25.57 \mathrm{a}$ & $37.00 \mathrm{abc}$ \\
$\mathrm{T} 15$ & $139.7 \mathrm{a}$ & $25.83 \mathrm{a}$ & $17.83 \mathrm{abc}$ & $90.23 \mathrm{~b}-\mathrm{f}$ & $16.37 \mathrm{cde}$ & $25.77 \mathrm{a}$ & $37.77 \mathrm{ab}$ \\
$\mathrm{T}_{16}$ & $143.2 \mathrm{a}$ & $25.87 \mathrm{a}$ & $18.00 \mathrm{ab}$ & $87.37 \mathrm{c}-\mathrm{f}$ & $16.10 \mathrm{c}-\mathrm{f}$ & $25.87 \mathrm{a}$ & $38.00 \mathrm{a}$ \\
\hline $\mathrm{LSD}_{0.05}$ & 10.24 & 1.431 & 1.447 & 9.307 & 3.722 & 1.396 & 2.343 \\
\hline
\end{tabular}

Values followed by different small letters within columns are significantly different $(p<0.05)$ according to the LSD test 

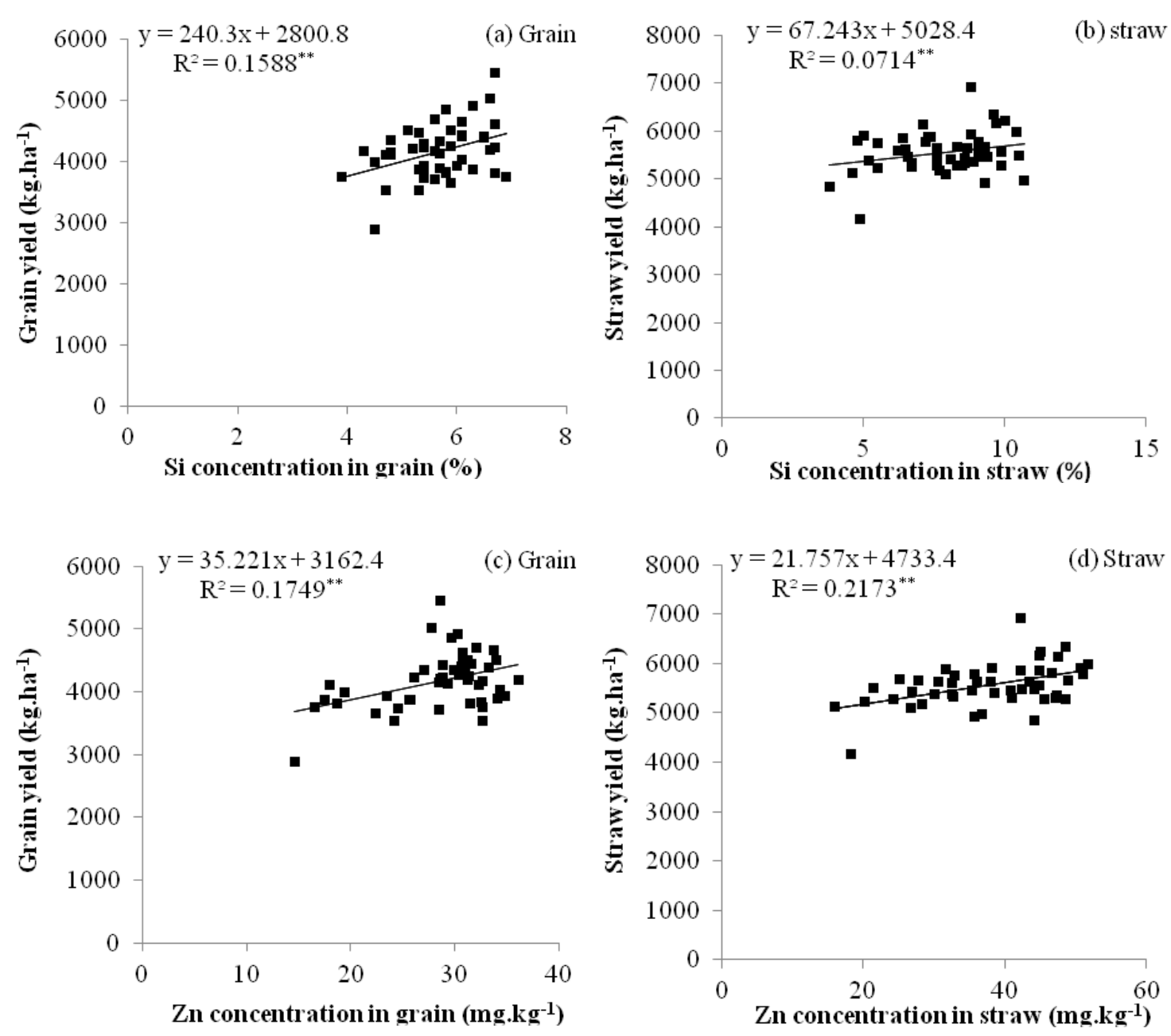

Figure 3. The relationship of Si concentration in grain (a) and straw (b) with grain and straw yields of rice, correlations of Zn concentration in grain (c) and straw $(d)$ with grain and straw yields of rice under the influence of experimental treatments

\section{Fertile tiller number per hill}

$\mathrm{Si}$ and $\mathrm{Zn}$ application significantly increased the number of fertile tiller per hill. The maximum fertile tiller number per hill (18.47 tiller) was obtained by simultaneous foliar application of nano- $\mathrm{SiO}_{2}+$ nano- $\mathrm{ZnO}(\mathrm{T} 13)$, and this trait was reduced under control condition by $28.9 \%$ (Table 6 ).

\section{Filled and unfilled grain number, 1000-grain weight}

The results of this experiment showed that the number of filled and unfilled grains per panicle were significantly affected by the experimental treatments. The highest number of filled grains per panicle (100 whole grain) was obtained by combined application of nano- $\mathrm{SiO}_{2}$ foliar spray + calcium silicate soil application (T6), and with no fertilizer application (control), the trait was reduced by $18.4 \%$. Also, the lowest number of unfilled grain per panicle was observed in the treatments of T6 and T14. The effect of experimental treatments was not significant on 1000-grain weight (Table 6). 


\section{Chlorophyll content of flag leaf}

By Si and $\mathrm{Zn}$ application the chlorophyll content of flag leaf improved compared to the control, such that the maximum chlorophyll content (38.00) was obtained by T16 treatment application, whereas without applying $\mathrm{Si}$ and $\mathrm{Zn}$, this trait was reduced by $7.8 \%$ (Table 6).

\section{Si concentration in grain and straw}

A significant increase in Si concentration in plant tissue was observed by NPs foliar application and soil application of elements. Mean comparison indicated that the $\mathrm{Si}$ concentration in grain $(6.40 \%)$ and straw $(9.80 \%)$ of rice was significantly increased by combined application of $\mathrm{Si}$ and $\mathrm{Zn}$ in both methods of NPs foliar application and soil application (T16). The lowest $\mathrm{Si}$ concentration in grain and straw of rice was observed in the control or no fertilizer application (T1). The application of T9 treatment increased the Si mobilization efficiency index (1.01) because of the better transfer of Si from straw to seed and consequently its accumulation in grain (Table 7).

Table 7. Mean comparison of the effects of experimental treatments on Si concentrations in grain and straw of rice (cv. Tarom Hashemi)

\begin{tabular}{c|c|c|c}
\hline Treatments & Si concentration in grain $(\%)$ & Si concentration in straw (\%) & Si MEI \\
\hline $\mathrm{T} 1$ & $4.60 \mathrm{e}$ & $5.40 \mathrm{e}$ & $0.85 \mathrm{ab}$ \\
$\mathrm{T} 2$ & $5.36 \mathrm{a}-\mathrm{e}$ & $6.63 \mathrm{de}$ & $0.81 \mathrm{ab}$ \\
$\mathrm{T} 3$ & $4.93 \mathrm{de}$ & $6.00 \mathrm{e}$ & $0.82 \mathrm{ab}$ \\
$\mathrm{T} 4$ & $5.60 \mathrm{a}-\mathrm{e}$ & $7.10 \mathrm{~b}-\mathrm{e}$ & $0.79 \mathrm{ab}$ \\
$\mathrm{T} 5$ & $5.83 \mathrm{a}-\mathrm{d}$ & $8.60 \mathrm{a}-\mathrm{d}$ & $0.67 \mathrm{~b}$ \\
$\mathrm{~T} 6$ & $6.00 \mathrm{abc}$ & $9.00 \mathrm{abc}$ & $0.66 \mathrm{~b}$ \\
$\mathrm{~T} 7$ & $5.90 \mathrm{a}-\mathrm{d}$ & $8.80 \mathrm{abc}$ & $0.68 \mathrm{~b}$ \\
$\mathrm{~T} 8$ & $6.30 \mathrm{ab}$ & $9.40 \mathrm{a}$ & $0.66 \mathrm{~b}$ \\
$\mathrm{~T} 9$ & $5.33 \mathrm{~b}-\mathrm{e}$ & $5.80 \mathrm{e}$ & $1.01 \mathrm{a}$ \\
$\mathrm{T} 10$ & $5.46 \mathrm{a}-\mathrm{e}$ & $7.00 \mathrm{cde}$ & $0.82 \mathrm{ab}$ \\
$\mathrm{T} 11$ & $5.03 \mathrm{cde}$ & $6.30 \mathrm{e}$ & $0.85 \mathrm{ab}$ \\
$\mathrm{T} 12$ & $5.70 \mathrm{a}-\mathrm{d}$ & $7.33 \mathrm{~b}-\mathrm{e}$ & $0.77 \mathrm{ab}$ \\
$\mathrm{T} 13$ & $6.00 \mathrm{abc}$ & $9.06 \mathrm{ab}$ & $0.66 \mathrm{~b}$ \\
$\mathrm{~T} 14$ & $6.36 \mathrm{ab}$ & $9.50 \mathrm{a}$ & $0.66 \mathrm{~b}$ \\
$\mathrm{~T} 15$ & $6.10 \mathrm{ab}$ & $8.91 \mathrm{abc}$ & $0.68 \mathrm{~b}$ \\
$\mathrm{~T} 16$ & $6.40 \mathrm{a}$ & $9.80 \mathrm{a}$ & $0.64 \mathrm{~b}$ \\
\hline $\mathrm{LSD}_{0.05}$ & 1.056 & 2.010 & 0.2983 \\
\hline
\end{tabular}

Values followed by different small letters within columns are significantly different $(p<0.05)$ according to the LSD test

\section{Zn concentration in grain and straw}

The effect of experimental treatments was significant on $\mathrm{Zn}$ concentration in rice plant tissue. However, by combined application of $\mathrm{Si}$ and $\mathrm{Zn}$ in the form of soil and foliar application, Zn concentration was increased in grain and straw. The maximum $\mathrm{Zn}$ concentration in grain (32.90 mg. $\left.\mathrm{kg}^{-1}\right)$, was obtained by treatments of $\mathrm{T} 16$, while the maximum $\mathrm{Zn}$ concentration in straw (48.80 and $48.50 \mathrm{mg} \cdot \mathrm{kg}^{-1}$ ) was obtained by 
treatments of T15 and T16, respectively. Zn mobilization efficiency index did not differ significantly in the fertilized treatments (Table 8). According to Figure 4, the $\mathrm{Zn}$ concentration changed by changes in $\mathrm{Si}$ concentration, such that by increasing $\mathrm{Si}$ concentration in plant tissue, $\mathrm{Zn}$ concentration in grain and straw increased $\left(\mathrm{R}^{2}=0.1664\right.$ and $\mathrm{R}^{2}=0.1642, \mathrm{P}<0.01$, respectively).

Table 8. Mean comparison of the effects of the experimental treatments on Zn concentrations in grain and straw of rice (cv. Tarom Hashemi)

\begin{tabular}{c|c|c|c}
\hline Treatments & $\begin{array}{c}\text { Zn concentration in grain } \\
\left(\mathbf{m g . k g}^{-\mathbf{1}}\right)\end{array}$ & $\begin{array}{c}\text { Zn concentration in straw } \\
\left(\mathbf{m g} \cdot \mathbf{k g} \mathbf{g}^{-1}\right)\end{array}$ & Zn MEI \\
\hline $\mathrm{T} 1$ & $16.20 \mathrm{e}$ & $19.50 \mathrm{~h}$ & $0.84 \mathrm{a}$ \\
$\mathrm{T} 2$ & $21.63 \mathrm{~d}$ & $25.90 \mathrm{gh}$ & $0.87 \mathrm{a}$ \\
$\mathrm{T} 3$ & $27.80 \mathrm{bc}$ & $34.50 \mathrm{~d}-\mathrm{g}$ & $0.81 \mathrm{a}$ \\
$\mathrm{T} 4$ & $28.40 \mathrm{abc}$ & $36.30 \mathrm{c}-\mathrm{f}$ & $0.79 \mathrm{a}$ \\
$\mathrm{T} 5$ & $23.70 \mathrm{~cd}$ & $28.20 \mathrm{fgh}$ & $0.84 \mathrm{a}$ \\
$\mathrm{T} 6$ & $24.20 \mathrm{~cd}$ & $28.70 \mathrm{efg}$ & $0.89 \mathrm{a}$ \\
$\mathrm{T} 7$ & $30.30 \mathrm{ab}$ & $37.50 \mathrm{~b}-\mathrm{e}$ & $0.82 \mathrm{a}$ \\
$\mathrm{T} 8$ & $30.50 \mathrm{ab}$ & $38.30 \mathrm{bcd}$ & $0.79 \mathrm{a}$ \\
$\mathrm{T} 9$ & $30.30 \mathrm{ab}$ & $38.50 \mathrm{bcd}$ & $0.79 \mathrm{a}$ \\
$\mathrm{T} 10$ & $30.60 \mathrm{ab}$ & $40.40 \mathrm{a}-\mathrm{d}$ & $0.76 \mathrm{a}$ \\
$\mathrm{T} 11$ & $31.70 \mathrm{ab}$ & $42.10 \mathrm{a}-\mathrm{d}$ & $0.75 \mathrm{a}$ \\
$\mathrm{T} 12$ & $31.50 \mathrm{ab}$ & $43.60 \mathrm{abc}$ & $0.72 \mathrm{a}$ \\
$\mathrm{T} 13$ & $31.80 \mathrm{ab}$ & $45.20 \mathrm{abc}$ & $0.69 \mathrm{a}$ \\
$\mathrm{T} 14$ & $32.00 \mathrm{ab}$ & $46.20 \mathrm{ab}$ & $0.69 \mathrm{a}$ \\
$\mathrm{T} 15$ & $32.60 \mathrm{ab}$ & $48.80 \mathrm{a}$ & $0.66 \mathrm{a}$ \\
$\mathrm{T} 16$ & $32.90 \mathrm{a}$ & $48.50 \mathrm{a}$ & $0.67 \mathrm{a}$ \\
\hline $\mathrm{LSD}_{0.05}$ & 4.944 & 9.026 & 0.2529 \\
\hline
\end{tabular}

Values followed by different small letters within columns are significantly different $(\mathrm{p}<0.05)$ according to the LSD test
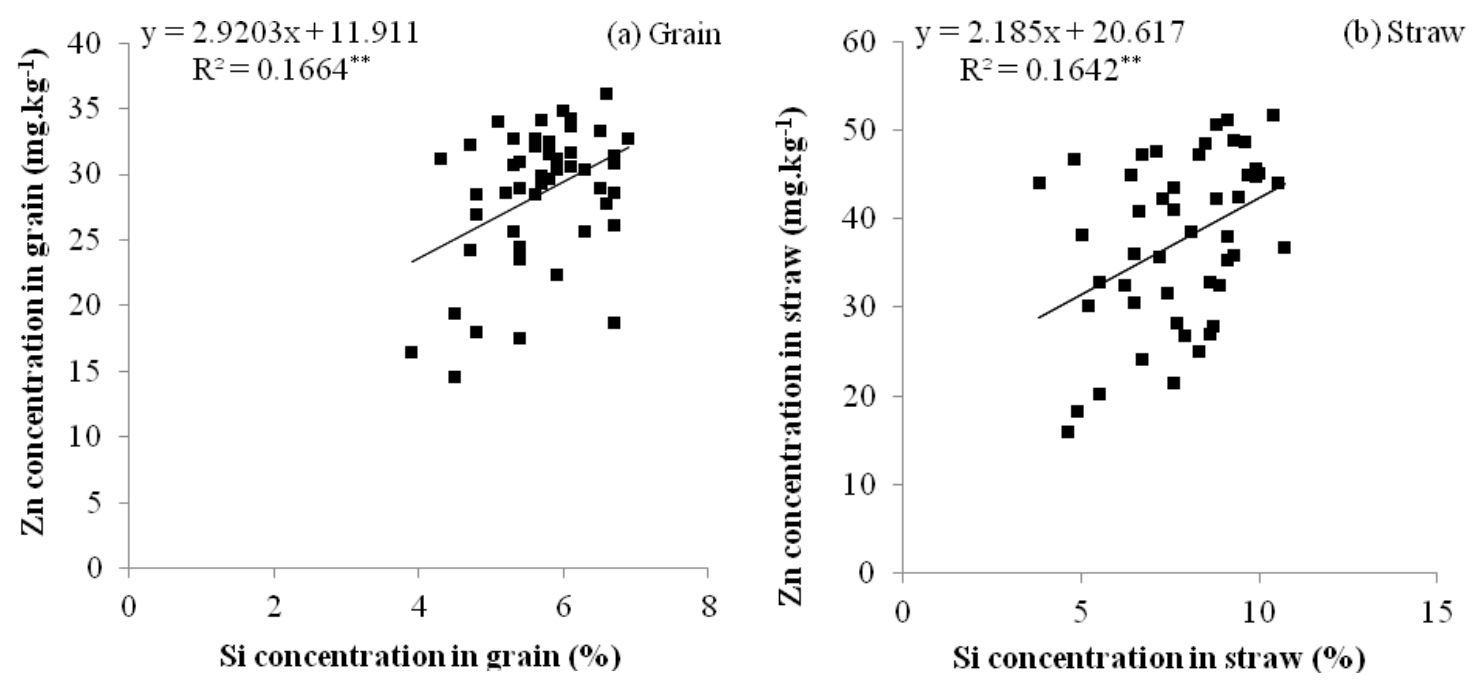

Figure 4. The relationship of Si concentration in grain (a) and straw (b) and Zn concentration in grain and straw of rice under experimental treatments 


$$
-5791 \text { - }
$$

\section{$N$ concentration in grain and straw}

The $\mathrm{N}$ concentration in grain and straw was increased by $\mathrm{Si}$ and $\mathrm{Zn}$ application. The NPs foliar application and soil application of Si and Zn significantly improved the $\mathrm{N}$ concentration in plant tissue compared to control. The maximum $\mathrm{N}$ concentration in grain was obtained by treatments of T14, T15 and T16. Also, the T15 and T16 treatments had the highest $\mathrm{N}$ concentration in rice straw. The maximum $\mathrm{N}$ mobilization efficiency index in rice plant was observed by $\mathrm{T} 1$ treatment or control (Table 9). There was a positive and significant linear correlation between $\mathrm{N}$ concentrations in plant tissue with the $\mathrm{Si}$ and $\mathrm{Zn}$ concentration in grain and straw at a probability level of $1 \%$, such that by increasing $\mathrm{Si}$ concentration in grain and straw $\left(\mathrm{R}^{2}=0.0655\right.$ and $\mathrm{R}^{2}=0.1859$, $P<0.01$, respectively), and $\mathrm{Zn}$ concentration in grain and straw $\left(R^{2}=0.1902\right.$ and $\mathrm{R}^{2}=0.4708, \mathrm{P}<0.01$, respectively), $\mathrm{N}$ concentrations in grain and straw increased (Fig. 5).

Table 9. Mean comparison of the effects of the experimental treatments on $N$ concentrations in grain and straw of rice (cv. Tarom Hashemi)

\begin{tabular}{c|c|c|c}
\hline Treatments & N concentration in grain (\%) & N concentration in straw (\%) & N MEI \\
\hline $\mathrm{T} 1$ & $1.36 \mathrm{c}$ & $0.569 \mathrm{~d}$ & $2.40 \mathrm{a}$ \\
$\mathrm{T} 2$ & $1.39 \mathrm{bc}$ & $0.622 \mathrm{~cd}$ & $2.25 \mathrm{ab}$ \\
$\mathrm{T} 3$ & $1.43 \mathrm{abc}$ & $0.670 \mathrm{bcd}$ & $2.14 \mathrm{ab}$ \\
$\mathrm{T} 4$ & $1.44 \mathrm{abc}$ & $0.718 \mathrm{abc}$ & $2.01 \mathrm{ab}$ \\
$\mathrm{T} 5$ & $1.43 \mathrm{abc}$ & $0.656 \mathrm{bcd}$ & $2.18 \mathrm{ab}$ \\
$\mathrm{T} 6$ & $1.43 \mathrm{abc}$ & $0.668 \mathrm{bcd}$ & $2.13 \mathrm{ab}$ \\
$\mathrm{T} 7$ & $1.46 \mathrm{abc}$ & $0.751 \mathrm{abc}$ & $1.95 \mathrm{~b}$ \\
$\mathrm{~T} 8$ & $1.47 \mathrm{abc}$ & $0.767 \mathrm{ab}$ & $1.97 \mathrm{~b}$ \\
$\mathrm{~T} 9$ & $1.45 \mathrm{abc}$ & $0.718 \mathrm{abc}$ & $2.03 \mathrm{ab}$ \\
$\mathrm{T} 10$ & $1.48 \mathrm{abc}$ & $0.707 \mathrm{abc}$ & $2.09 \mathrm{ab}$ \\
$\mathrm{T} 11$ & $1.50 \mathrm{abc}$ & $0.739 \mathrm{abc}$ & $2.03 \mathrm{ab}$ \\
$\mathrm{T} 12$ & $1.51 \mathrm{abc}$ & $0.774 \mathrm{ab}$ & $1.96 \mathrm{~b}$ \\
$\mathrm{~T} 13$ & $1.51 \mathrm{ab}$ & $0.785 \mathrm{ab}$ & $1.94 \mathrm{~b}$ \\
$\mathrm{~T} 14$ & $1.54 \mathrm{a}$ & $0.780 \mathrm{ab}$ & $1.97 \mathrm{~b}$ \\
$\mathrm{~T} 15$ & $1.54 \mathrm{a}$ & $0.823 \mathrm{a}$ & $1.90 \mathrm{~b}$ \\
$\mathrm{~T} 16$ & $1.55 \mathrm{a}$ & $0.816 \mathrm{a}$ & $1.90 \mathrm{~b}$ \\
\hline $\mathrm{LSD}_{0.05}$ & 0.1491 & 0.1292 & 0.3981 \\
\hline
\end{tabular}

Values followed by different small letters within columns are significantly different $(\mathrm{p}<0.05)$ according to the LSD test

\section{Discussion}

The increase of the grain and straw yields with simultaneous application of $\mathrm{Si}$ and $\mathrm{Zn}$ can be attributed to the positive and synergistic effects between silicon and zinc, which by increasing the Si and $\mathrm{Zn}$ uptake, as well as increasing the fertile tiller number per hill lead to an increase in yields. There were synergistic interactions between $\mathrm{Si}$ and $\mathrm{Zn}$, which ultimately has contributed to increased absorption of these elements in the plant tissue (Ghasemi et al., 2014). In the present study, in terms of an increase in yields, the NPs foliar application slightly is better than soil application of these elements. The micronutrients in the form of nanoparticles are effective in producing and increasing the 


$$
-5792 \text { - }
$$

product yield (Reynolds, 2002). Amrullah et al. (2015) stated that nano- $\mathrm{SiO}_{2}$ is superior over conventional silicon fertilizer. Gradual release of nutrients during growth stages of the plant by nano-ZnO application increases growth and rice yield (Yuvaraj and Subramanian, 2014). Cuong et al. (2017) reported that by adding silicon, rice grain yield was improved due to increasing growth, yield components, and better absorption of nutrients. Silicon application, especially at reproductive stages increases the chlorophyll content, the number of fertile tiller per hill, percentage of filled spikelets, and finally improves rice grain yield (Tamai and Ma, 2008). Zinc application by both methods foliar application and soil application is suitable for improving grain yield and increasing profitability in various systems of rice production (Farooq et al., 2018). Saha et al. (2017) revealed that zinc supply through soil +2 foliar application caused the greatest increase in zinc concentration in rice grains by producing optimal grain yield, which confirms the results of the present study.
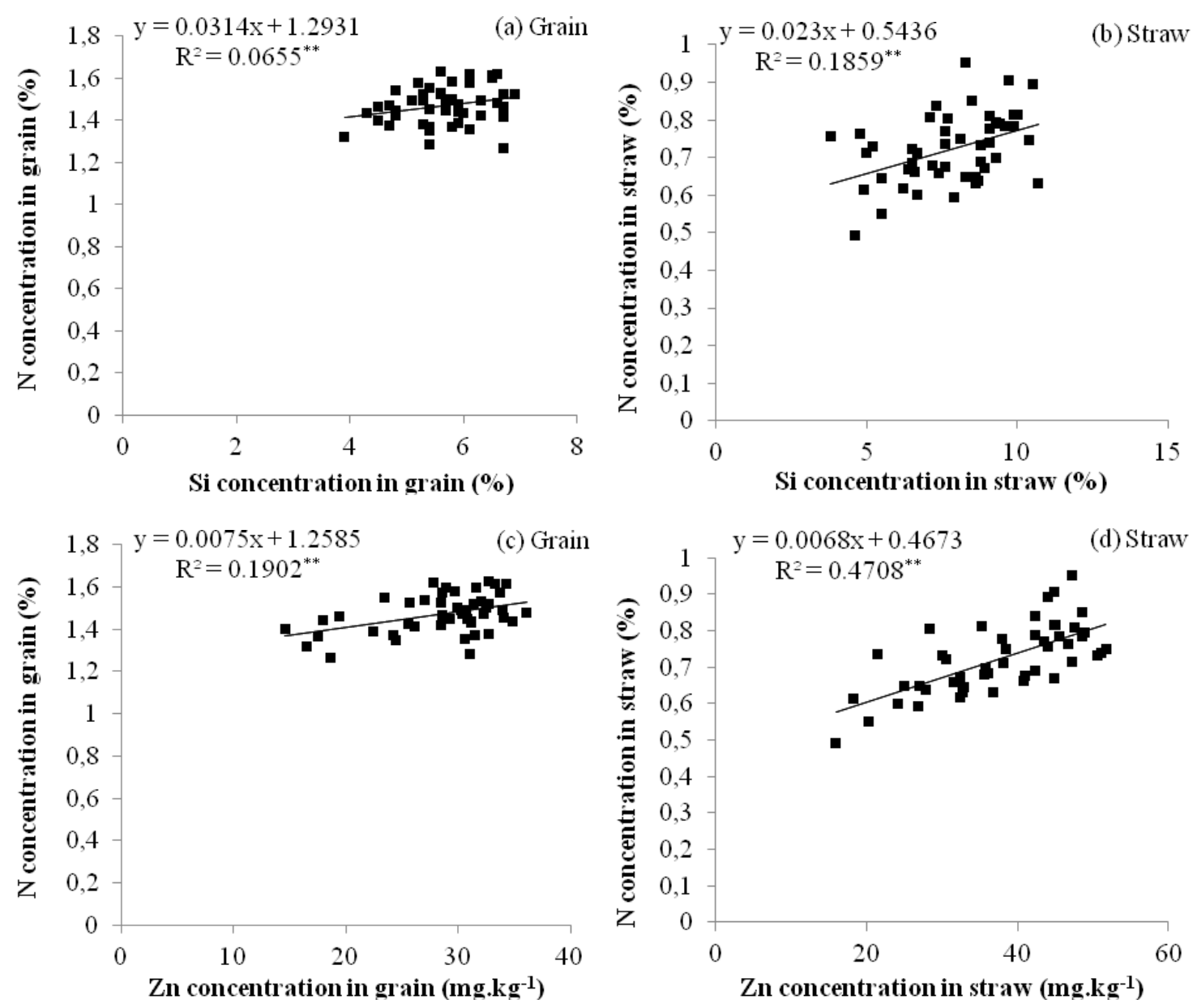

Figure 5. The relationship of Si concentration in grain (a) and straw (b) and $N$ concentration in grain and straw of rice, correlations of Zn concentration in grain (c) and straw (d) with $N$ concentration in grain and straw of rice under experimental treatments

It seems that the soil application of Si and $\mathrm{Zn}$ was less effective in improving panicle length than NPs foliar application, although it increased the trait compared to control. Although panicle length does not directly have a role in the calculation of grain yield, it 


$$
-5793 \text { - }
$$

is considered as one of the yield evaluation attributes (Jalali et al., 2015). Ghasemi Lamraski et al. (2014) reported that foliar application of nano- $\mathrm{SiO}_{2}$ caused a $1.4 \%$ increase in the panicle length compared to non-silicon application. According to Kamari et al. (2014) by foliar application of nano- $\mathrm{ZnO}$ significantly increased the panicle length of triticale.

By combined application of $\mathrm{Si}$ and $\mathrm{Zn}$ in both methods used, the number of fertile tillers per hill significantly increased compared to individual application of Si and $\mathrm{Zn}$. Zia et al. (2017) reported that the proper use of silicon has been effective in increasing the number of rice tillers, such that the application of $3 \mathrm{mM}$ of silicon caused a $19 \%$ increase in the number of tiller compared with the control. Application of zinc in both methods of soil and foliar application due to increased zinc concentration in plant leads to an increase in the number of effective tillers per square meter (Farooq et al., 2018). The supply of silicon and zinc by the plant through NPs foliar application increased the number of fertile tillers per hill compared to the soil method. In similar results, the researchers by studying different sources of silicon in the methods of soil and NPs foliar application reported that the maximum fertile tiller number per hill was obtained by nano- $\mathrm{SiO}_{2}$ foliar application for two crop years (Yazdpour et al., 2014a). The positive effect of zinc on increasing the number of fertile tillers per hill was quite evident over silicon so that in all treatments where zinc fertilizer was used to forms of NPs foliar application and soil application, the fertile tiller number was improved compared to silicon application, although using both elements increased the number of the fertile tiller per hill.

Reduction of the number of filled grains per panicle with no fertilizer application could be due to the lack of availability to nutrients and the reduction of photosynthetic seed distribution, but this trait was increased with the addition of $\mathrm{Si}$ and $\mathrm{Zn}$. The result showed that the number of filled grains per panicle significantly increased in treatments where silicon was used. Cuong et al. (2017) reported that the number of grains per panicle was increased by increasing silicon application. The silicon application in the reproductive stages of rice had a very positive effect on the improvement of the number of filled grains per panicle (Lavinsky et al., 2016), which confirms the results of this experiment. According to Tamai and Ma (2008), among the yield components, the percentage of filled spikelets was more affected by silicon fertilizer.

The grain size in rice is controlled by its shell, which shows that why the extent of 1000-grain weight changes is not high (Saha et al., 1998). Reports indicate that the 1000-grain weight was not affected by different concentrations of silicon (Yazdpour et al., 2014a), which is consistent with the results of the present research. In contrast, a piece of research showed that the zinc application from different sources had a significant effect on thousand grain weight of rice (Shivay et al., 2016).

By combined application of Si and $\mathrm{Zn}$ in both methods of NPs foliar application and soil application, the chlorophyll meter value increased compared to the separate application of these two element. Nano-Si has an important role in increasing the chlorophyll content of rice leaves (Wang et al., 2015). It was reported that application of nano-Zn oxide did not significantly affect the photosynthetic pigment content of different varieties of rice, but it protected photosynthetic pigments such as chlorophyll a and $\mathrm{b}$ in plant cells by improving the antioxidant enzymes activities (Samart et al., 2017). Zinc foliar application at the tillering stage of rice led to an increase in gene expression, carbonic anhydrase enzyme activation, improvement of the photosynthesis process and increase in relative chlorophyll concentration per unit leaf area (Qiao et al., 


$$
\text { - } 5794 \text { - }
$$

2014). Several reports have been presented by investigators regarding the effects of $\mathrm{Si}$ (Ranganathan et al., 2006) and Zn (Kabeya and Shankar, 2013) on increasing the chlorophyll content of plants, which is consistent with the results of this study.

In the present research, Si application increased the Si concentration in grain and straw of rice, and $\mathrm{Zn}$ application plus $\mathrm{Si}$ led to higher concentrations of $\mathrm{Si}$ in rice tissue. Reports indicated that the $\mathrm{Zn}$ application in the root increases the Si concentration in root and shoot (Mehrabanjoubani et al., 2015). Zia et al. (2017) found that by increasing silicon consumption from 0 to $3 \mathrm{mM}$, the Si concentration in root and shoot was increased by about 48 and 42\%, respectively. According to Yazdpour et al. (2014b) the highest $\mathrm{Si}$ concentration in rice was obtained by nano-Si foliar application in both years of study.

The $\mathrm{Zn}$ concentration in grain and straw was improved in all treatments in which $\mathrm{Zn}$ fertilizer was used to both methods of soil application and NPs foliar application. It has been reported that the zinc concentration in rice grains increased by $47 \%$ compared to control, when zinc fertilizer was applied through soil (basal) + foliar application at maximum tillering and flowering stages (Saha et al., 2017). Zinc application using four different methods (foliar application, soil application, seed priming and seed coating) significantly increased grain zinc concentration in various systems of rice production at two different sites (Farooq et al., 2018). Although the combined application of Si and $\mathrm{Zn}$ in soil application method led to an increase in grain and straw $\mathrm{Zn}$, the effect of combined application of elements by NPs foliar application method was greater than soil application. Si application by methods of soil application and NPs foliar application individually or in a combination of two methods could not significantly increase the grain and straw $\mathrm{Zn}$ concentration, but the Si application plus $\mathrm{Zn}$ significantly increased zinc concentration in rice tissue due to the synergistic interaction of these two elements. Similar to the results of this experiment, in previous studies the increase of $\mathrm{Zn}$ concentrations in rice plant tissue by the nano-Si application was reported (Wang et al., 2015).

In this research, it seems that role of $\mathrm{Zn}$ in improving $\mathrm{N}$ concentration was slightly more than $\mathrm{Si}$, although both elements were effective in improving $\mathrm{N}$ concentration. The $\mathrm{Zn}$ application increases the accumulation of amino acids and nitrogen metabolism in plant tissue (Sudha and Stalin, 2015). Reports indicate that the $\mathrm{N}$ uptake was improved by $\mathrm{Zn}$ application in two growing seasons (Kumar Naik and Kumar Das, 2008). The researchers revealed that there was a positive and significant linear relationship between the amount of silicon absorption and the uptake of nitrogen in rice plant (Cuong et al., 2017). According to Yazdpour et al. (2014b) the maximum N concentration and protein content of rice were obtained by the foliar application of nano-Si.

\section{Conclusion}

In this research, we investigated the effects of different resources and methods of silicon and zinc application on agronomic and physiological traits, as well as the grain and straw yield of rice in Mazandaran province. The results revealed that the application of $\mathrm{Si}$ and $\mathrm{Zn}$ in both methods of NPs foliar application and soil application had a positive effect on agronomic traits and seed yield, although the influence of $\mathrm{Zn}$ fertilizer on grain and straw yields improvement was slightly more than Si fertilizer. Also, in both methods, the foliar application of nanoparticles had better efficiency than soil application of the elements due to the small size of the particles and the ability to absorb 


$$
\text { - } 5795 \text { - }
$$

more of the elements by the plant. By combined application of $\mathrm{Si}$ and $\mathrm{Zn}$, many physiological characteristics such as the $\mathrm{Si}, \mathrm{Zn}$ and $\mathrm{N}$ concentrations in rice plant tissue, yield components and grain and straw yield of rice improved compared to separate application of each elements and control. The main reason for this increase could be synergistic effects between the two elements of silicon and zinc, such that the silicon caused the balance of nutrients in the plant and was a good supplement with zinc in improving the nutrients uptake and increasing grain yield.

Therefore, given that the simultaneous application of silicon and zinc, especially by foliar application of nanoparticles provides the nutrient required for the plant and improves grain production of rice, this fertilizer treatment is recommended for use in soils similar to the one used in this experiment.

Future extensions of this study for future research: It is recommended to investigate the quality of rice produced in the cultivar studied in these treatments. The experimental treatments on late rice varieties can be also studied. Moreover, the germination characteristics of seeds produced in these treatments, as well as the effect of these treatments on the absorption efficiency of the main elements of NPK can be evaluated. Also, the effects of other nano-fertilizers such as nano- $\mathrm{MgO}$ and nano- $\mathrm{Ag}$ in combination with the nanoparticles used in this experiment, as well as the effects of other fertilizer sources containing silicon and zinc such as potassium silicate and zinc chelate on physiological traits, rice growth and yield can be investigated. Besides, the absorption of other essential nutrients such as $\mathrm{P}, \mathrm{K}, \mathrm{S}, \mathrm{Ca}, \mathrm{Mg}, \mathrm{Fe}, \mathrm{Cu}, \mathrm{Mn}, \mathrm{B}$, as well as heavy metals such as $\mathrm{Cd}$, $\mathrm{As}$ and $\mathrm{Pb}$ in rice grains can be measured in order to determine the health status of rice seeds because rice seeds are fed by humans. Finally, the effects of silicon and zinc both in the form of nanoparticles and conventional method on rice grain yield by a foliar application can be studied.

\section{REFERENCES}

[1] Amiri, A., Bagheri, A., Khaje, M., Najafabadi Pour, F., Yadollahi, P. (2014): Effect of silicon foliar application on yield and antioxidant enzymes activity of safflower under limited irrigation conditions. - Journal of Agricultural Research 5(4): 361-372.

[2] Amirjani, M. R., Askari, M., Askari, F. (2014): Effect of nano zinc oxide on alkaloids, enzymatic and antienzymatic antioxidant contents and some physiological parameters of catharantus roseus. - Journal of Cell and Tissue 5(2): 173-183.

[3] Amrullah, Sopandie, D., Sugianta, Junaedi, A. (2015): Influence of nano-silica on the growth of rice plant (Oryza sativa L.). - Asian Journal of Agricultural Research 9(1): 3337.

[4] Boonyanitipong, P., Kositsup, B., Kumar, P., Baruah, S., Dutta, J. (2011): Toxicity of Zno and Tio2 nanoparticles on germination rice seed Oryza sativa L. - International Journal of Bioscience, Biochemistry and Bioinformatics 1(4): 282-285.

[5] Chang, H. B., Win, L., Huang, H. J. (2005): Zinc-induced cell death in rice (Oryza sativa L.) roots. - Plant Growth Regulation 46(3): 261-266.

[6] Chen, J., Liu, X., Wang, C., Yin, S. S., Li, X. L., Hu, W. J., Simon, M., Shen, Z. J., Xiao, Q., Chu, C. C., Peng, X. X. (2015): Nitric oxide ameliorates zink oxide nanoparticlesinduced phytotoxicity in rice seedlings. - Journal of Hazardous Materials 297: 173-182.

[7] Cuong, T. X., Ullah, H., Datta, A., Hanh, T. C. (2017): Effects of silicon-based fertilizer on growth, yield and nutrient uptake of rice in tropical zone of Vietnam. - Rice Science 24(5): 283-290.

[8] Emami, A. (1996): Methods of Plant Analysis. Vol. 982. - Soil and Water Res. Institute, Tehran. 
[9] Farooq, M., Ullah, A., Rehman, A., Nawaz, A., Nadeem, A., Wakeel, A., Nadeem, F., Siddique, K. H. M. (2018): Application of zinc improves the productivity and biofortification of fine grain aromatic rice grown in dry seeded and puddle transplanted production systems. - Field Crops Research 216: 53-62.

[10] Ghasemi, M., Mobasser, H. R., Asadimanesh, H., Gholizadeh, A. (2014): Investigating the effect of potassium, zinc and silicon on grain yield, yield components and their absorption in grain rice (Oryza sativa L.). - Electronic Journal of Soil Management and Sustainable Production 4: 1-24.

[11] Ghasemi Lemraski, M., Normohamadi, G., Madani, H., Heidari Sharifabad, H., Mobasser, H. R. (2014): Effect of silicon and potassium foliar application and nitrogen rates on yield and yield components of Iranian rice cultivars, Tarom Hashemi and Tarom Mahalli. - Journal of New Finding in Agriculture 9(1): 47-66.

[12] Ghasemi Mianaei, A., Mobasser, H. R., Madani, H., Dastan, S. (2011): Silicon and potassium application facts on lodging related characteristics and quantity yield in rice (Oryza sativa L.) Tarom Hashemi variety. - Journal of New Finding in Agriculture 5(4): 423-435.

[13] He, Y. P., Zhang, J. F., Chen, J. M. (2014): Effect of synergists on susceptibility to chlorantraniliprole in field populations of Chilo suppressalis (Lepidoptera: Pyralidae). Journal of Economic Entomology 107: 791-796.

[14] Huang, S., Wang, L., Liu, L., Hou, Y., Li, L. (2015): Nanotechnology in agriculture, livestock, and aquaculture in China, A review. - Agronomy for Sustainable Development 35: 369-400.

[15] Jalali, J., Nasiri, M., Habibi, M., Kheyri, N. (2015): Evaluation of possibility of increasing success coefficient of direct seeding of rice genotypes by changing sowing dates. - Crop Physiology Journal 7(26): 85-103.

[16] Jeer, M., Telugu, U. M., Voleti, S. R., Padmakumari, A. P. (2017): Soil application of silicon reduces yellow stem borer, scripophage incertulas (Walker) damage in rice. Journal of Applied Entomology 141(3): 189-201.

[17] Jianguo, L., Hui, C., Congcong, M., Mingxin, W. (2015): Effects of nano-silicon and common silicon on lead uptake and translocation in two rice cultivars. - Frontiers of Environmental Science and Engineering 1-7.

[18] Kabeya, M. J., Shankar, A. G. (2013): Effect of different levels of zinc on growth and uptake ability in rice zinc contrast lines (Oryza sativa L.). - Asian Journal of Plant Science and Research 3(3): 112-116.

[19] Kafi, M., Rahimi, Z. (2011): Effect of salinity and silicon on root characteristics, growth water status, proline content and ion accumulation of purslane (Portulaca oleracea L.). Soil Science and Plant Nutrition 57: 341-347.

[20] Kamari, H., Seyed Sharifi, R., Sedghi, M. (2014): Effect of Nano Zinc oxide foliar application and application of free living nitrogen fixing bacteria on yield and morphophysiological characteristics of Triticale. - Crop Physiology Journal 6(22): 37-52.

[21] Kumar Naik, S., Kumar Das, D. (2008): Relative performance of chelated zink and zink sulfate for lowland rice (Oryza sativa L.). - Nutrient Cycling in Agroecosystems 81: 219227.

[22] Lavinsky, A. O., Detmann, K. C., Reis, J. V., Avila, R. T., Sanglard, M. L., Pereira, L. F., Sanglard, L. M. V. P., Rodrigues, F. A., Araujo, W. L., DaMatta, F. M. (2016): Silicon improves rice grain yield and photosynthesis specifically when supplied during the reproductive growth stage. - Journal of Plant Physiology 206: 125-132.

[23] Lin, H., Fang, C., Li, Y., Lin, W., He, J., Lin, R., Lin, W. (2016): Effect of silicon on grain yield of rice under cadmium-stress. - Acta Physiologiae Plantarum 38-186.

[24] Lou, Y. S., Wu, L., Lixuan, R., Meng, Y., Shidi, Z., Huaiwei, Z. (2016): Effects of silicon application on diurnal variations of physiological properties of rice leaves of plants at the heading stage under elevated UV-B radiation. - International Journal of Biometeorology 60(2): 311-318. 
[25] Mahmoud, E., Abdel-Haliem, F., Hegazy, H. S., Hassan, N. S., Naguib, D. M. (2017): Effect of silica ions and nano silica on rice plants under salinity stress. - Ecological Engineering 99: 282-289.

[26] Mazlomi, M., Pirzad, A., Zardoshti, M. (2012): Allocation ratio of photosynthate to different parts of sugar beet plant affected by nano-iron foliar application at varying growth stages. - International Journal of Plant, Animal and Environmental Sciences 2: 121-128.

[27] Meena, V. D., Dotaniya, M. L., Coumar, V., Rajendiran, S., Ajay, Kundu, S., Rao, A. S. (2014): A case for silicon fertilization to improve crop yields in tropical soils. Proceedings of the National Academy of Sciences, India Section B: Biological Sciences 84(3): 505-518.

[28] Mehrabanjoubani, P., Abdolzadeh, A., Sadeghipour, H. R., Aghdasi, M. (2015): Impacts of silicon nutrition on growth and nutrient status of rice plants grown under varying zinc regimes. - Theoretical and Experimental Plant Physiology 27(1): 19-29.

[29] Mobasser, H. R., Ghanbari-Malidareh, A., Sedghi, A. H. (2008): Effect of silicon application to nitrogen rate and splitting on agronomical characteristics of rice (Oryza sativa L.). - Silicon in Agriculture Conference, Wild Coast Sun, South Africa, 26-31 October.

[30] Qiao, X., He, Y., Wang, Z., Li, X., Zhang, K., Zeng, H. (2014): Effect of foliar spray of zinc on chloroplast $\beta$-carbonic anhydrase expression and enzyme activity in rice (Oryza sativa L.) leaves. - Acta Physiologiae Plantarum 36: 263-272.

[31] Ranganathan, S., Suvarchala, V., Rajesh, Y. B. R. D., Prasad, M. S., Padmakumari, A. P. and Voleti, S. R. (2006): Effects of silicon sources on its deposition, chlorophyll content, and disease and pest resistance in rice. - Biologia Plantarum 50(4): 713-716.

[32] Reynolds, G. H. (2002): Forward to the future nanotechnology and regulatory policy. Pacific Research Institute 24: 1-23.

[33] Saha, A., Sarkar, R. K., Yamagishi, Y. (1998): Effect of time of nitrogen application on spikelet differentiation and degeneration of rice. - Botanical Bulletin of Academia Sinica. 39: 119-123.

[34] Saha, S., Chakraborty, M., Padhan, D., Saha, B., Murmu, S., Batabyal, K., Seth, A., Hazra, G. C., Mandal, B., Bell, R. W. (2017): Agronomic biofortification of zinc in rice: influence of cultivars and zinc application methods on grain yield and zinc bioavailability. - Field Crops Research 210: 52-60.

[35] Samart, S., Chutipaijit, S., Phakamas, N. (2017): Evaluating the effect of zinc oxide nanoparticles on the physiological responses of nine non-photoperiod sensitive rice cultivars. - Materials Today: Proceedings 4: 6430-6435.

[36] Sepehri, A., Vaziri Amjad, Z. (2015): The effect of iron and zinc nano fertilizers on quantitative yield of chicory (Cichorium inyubus L.) in different crop densities. - Journal of Agricultural Science and Sustainable Production 25(2.1): 61-74.

[37] Shivay, Y. S., Prasad, R., Kaur, R., Pal, M. (2016): Relative efficiency of zinc sulphate and chelated zinc on zinc biofortification of rice grains and zinc use-efficiency in Basmati rice. - Proceedings of the National Academy of Sciences, India Section B, Biological Sciences 86(4): 973-984.

[38] Sudha, S., Stalin, P. (2015): Effect of zinc on yield, quality and grain zinc content of rice genotypes. - International Journal of Farm Sciences 5(3): 17-27.

[39] Tamai, K., Ma, J. F. (2008): Reexamination of silicon effects on rice growth and production under field conditions using a low silicon mutant. - Plant Soil 307: 21-27.

[40] Upadhyaya, H., Shome, S., Tewari, S., Bhattacharya, M. K., Panda, S. K. (2014): Effect of $\mathrm{Zn}$ nano-particles on growth responses of rice. - Nano Science Technology Conference pp. 508-512.

[41] Wang, S., Wang, F., Gao, S. (2015): Foliar application with nano-silicon alleviates cd toxicity in rice seedlings. - Environmental Science and Pollution Research 22(4): 28372845 . 
[42] Wu, C., Zou, Q., Xue, S., Mo, J., Pan, W., Lou, L., Wong, M. H. (2015): Effects of silicon ( $\mathrm{Si}$ ) on arsenic (As) accumulation and speciation in rice (Oryza sativa L.) genotypes with different radial oxygen loss (Rol). - Chemosphere 138: 447-453.

[43] Yakan, H., Ali Gurbu, M., Ferzan, A., Halil, S., Necmi, B. (2000): The effect of zinc application on rice yield and some agronomic characters. http://om.ciheam.org/article.php?IDPDF=3400079.

[44] Yazdpour, H., Noormohamadi, G., Madani, H., Heidari Sharif Abad, H., Mobasser, H. R. (2014a): Role of nano-silicon and other silicon resources with nitrogen and phosphorus application on yield and yield components of rice (Oryza sativa L.). - Trends in Life Sciences. An International Peer-Reviewed Journal 3(2): 36-41.

[45] Yazdpour, H., Noormohamadi, G., Madani, H., Heidari Sharif Abad, H., Mobasser, H. R., Oshri, M. (2014b): Role of nano-silicon and other silicon resources on straw and grain protein, phosphorus and silicon contents in Iranian rice cultivar (Oryza sativa cv. Tarom). - International Journal of Biosciences 5(12): 449-456.

[46] Yoshida, S. (1975): The physiology of silicon in rice. - Food and Fertilizer Technology Center (FFTC), Technical Bulletin 25: 1-27.

[47] Yuvaraj, M., Subramanian, K. S. (2014): Fabrication of zinc nano fertilizer on growth parameter of rice. - Trends in Biosciences 7: 2564-2565.

[48] Zia, Z., Bakhat, H. F., Saqib, Z. A., Shah, G. M., Fahad, S., Ashraf, M. R., Hammad, H. M., Naseem, W., Shahid, M. (2017): Effect of water management and silicon on germination, growth, phosphorus and arsenic uptake in rice. - Ecotoxicology and Environmental Safety 144: 11-18. 